\title{
ETYCZNO-ANTROPOLOGICZNE ASPEKTY ABORCJI W ŚWIETLE KLASYCZNEJ LITERATURY GRECJI I RZYMU
}

W starożytności aborcja była faktem; dotyczyło to również starożytnej Grecji i Rzymu. Sokrates, dodajmy, syn akuszerki, mówiąc o pracy położnych stwierdza:

„Czyż nie jest prawdą, że również położne podając leki i śpiewając piosenki, mogą wywoływać bóle, osłabiać je, jeśli chca, oraz dokonywać trudnych porodów, a jeśli nowa istota wydaje się być bliska poronienia, dokonują poronienia"1.

Użyte w tym tekście greckie słowo ỏ $\mu \beta \lambda i ́ \sigma \kappa \varepsilon \imath v$ oznacza „poronić”, „,dokonać poronienia”. Ciekawą wzmiankę na temat zjawiska przerywania ciąży znajdujemy także w jednej z tragedii Eurypidesa, Andromacha. Tytułowa bohaterka zapewnia swego męża Menelaosa, że nie podawała jego córce żadnych środków poronnych ${ }^{2}$ :

„Jeśli bowiem podawałyśmy twej córce leki i spowodowałyśmy poronienie jej łona"3.

Użyty w tym zdaniu czasownik $\dot{\varepsilon} \xi \alpha \mu \beta \lambda$ ov̂v oznacza „wywołać poronienie”. Zarówno wypowiedź Sokratesa, jak i fragment dzieła wybitnego greckiego tragika, wskazują na jedno: w starożytnej Grecji przerywanie ciąży było zjawiskiem oczywistym. To samo dotyczy Cesarstwa Rzymskiego, a wiele świadectw na ten temat znajdujemy także w literaturze łacińskiej. Juwenalis w jednej z satyr mówi o wielu sztucznych poronieniach płodów poczętych przez Julię z cesarzem Domicjanem ${ }^{4}$. O postawie Domicjana w tym względzie

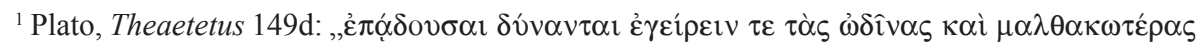

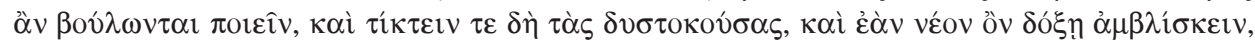
$\alpha \mu \beta \lambda i \sigma \kappa о v \sigma \imath "$ ".

${ }^{2}$ Por. S. Longosz, Ojcowie Kościoła a przerywanie ciaży, cz. 1: W okresie przedchrześcijańskim, VoxP 5 (1985) z. 8-9, 231-273, spec. 236.

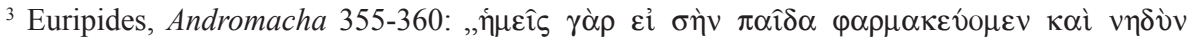
$\dot{\varepsilon} \xi \alpha \mu \beta \lambda \mathrm{ov} \mu \varepsilon v[\ldots] ”$...

${ }^{4}$ Por. Iuvenalis, Satura II 32-33: „Cum tot abortivis fecundam Iulia vulvam solveret [...]”; zob. 
informuje nas także w swych Vitae Caesarum Swetoniusz:

„Wkrótce po śmierci jej ojca i męża, rozmiłował się w niej gorąco i jawnie. Sam stał się przyczyną jej śmierci, gdyż zmusił ją do usunięcia płodu (abigere conceptum), poczętego z jego przyczyny"s.

Podobne świadectwo o tym wydarzeniu znajdziemy również $\mathrm{w}$ jednym $\mathrm{z}$ listów Pliniusza Młodszego ${ }^{6}$. Także historyk Tacyt wspomina, jak cesarz Neron chcąc się pozbyć Oktawii, która była jego prawowitą żoną, oskarżył ją między innymi o aborcję (abigere partum), chociaż wcześniej zarzucał jej bezpłodność ${ }^{7}$. Również wcześniej komediopisarz Plaut w jednej ze swych komedii wspomina o kobiecie, która ukrywała się przed mężczyzną, by ten nie zmusił jej do przerwania ciąży (abortioni operam) i uśmiercenia w ten sposób dziec$\mathrm{ka}^{8}$. Wreszcie Marek Tuliusz Cyceron w jednej ze swoich mów obrończych wspomina, że niejaki Opianik zapłacił jednej z wdów, znajdującej się w ciąży, by dokonała spędzenia płodu (merces abortionis), a potem razem z nią odziedziczył majątek ${ }^{9}$.

Skoro zarówno w starożytnej Grecji, jak i Rzymie aborcja była faktem, rodzi się pytanie, jak te antyczne społeczeństwa oceniały to zjawisko pod względem moralnym? Czy przerwanie ciąży uważano za dopuszczalne, czy też wręcz przeciwnie, jako karygodną zbrodnię? I jeszcze jedno istotne pytanie, które ma wymiar antropologiczny i należy je tutaj postawić: czy ludzie antyku uznawali ludzki płód za pełnego człowieka, który posiada zarówno ciało jak i duszę? A jeśli tak, to w jakim momencie dochodzi do animacji płodu? Jakie świadectwa $\mathrm{w}$ tym względzie przynosi nam klasyczna literatura grecka i rzymska? Przyjrzyjmy się wybranym autorom i ich wypowiedziom na ten temat.

Rozpocznijmy ten przegląd od dramatów Ajschylosa. W tragedii Eumeni$d y$ przedstawiony jest przez poetę Apollon Delficki, który odpędza od swego

Longosz, Ojcowie Kościoła, s. 242.

${ }^{5}$ Suetonius Tranquillus, Vitae Caesarum. Domitianus 22: „mox patre ac uiro orbatam ardentissime palamque dilexit, ut etiam causa mortis extiterit coactae conceptum a se abigere", thum. J. Niemirska-Pliszczyńska; Swetoniusz Trankwillus, Żywoty Cezarów, Warszawa 1965, 458.

${ }^{6}$ Por. Plinius Caecilius Secundus, Epistulae IV 11, 6: „Nec minore scelere quam quod ulcisci videbatur, absentem inauditamque damnavit incesti, cum ipse fratris filiam incesto non polluisset solum verum etiam occidisset; nam vidua abortu periit", por. tłum. Z. Ziółecki, Pliniusza Cecyliusza Listy, I, Wrocław 1837, 305; zob. Longosz, Ojcowie Kościoła, s. 242.

${ }^{7}$ Por. Tacitus, Annales XIV 63: „At Nero praefectum in spem sociandae classis corruptum et incusatae paulo ante sterilitatis oblitus, abactos partus conscientia libidinum, eaque sibi comperta edicto memorat insulaque Pandateria Octaviam claudit”, thum. S. Hammer: Tacyt, Dzieła, I, 434435; zob. także Longosz, Ojcowie Kościoła, s. 242.

${ }^{8}$ Por. Plautus, Truculentus 200-201: „Celabat metuebatque te, ne tu sibi persuaderes, ut abortioni operam daret puerumque ut enicaret”, por tłum. G. Przychocki: T.M. Plautus, Komedie, III, Kraków 1937, 412.

${ }^{9}$ Por. Cicero, Oratio pro Cluento Avito 12, 34; zob. Longosz, Ojcowie Kościoła, s. 237. 
proroczego przybytku Erynię, zalecając jej iść do otchłani największych kaźni i męczarni, gdzie przebywają mordercy, oszuści, trzebiciele chłopców i kobiety, które przerwały ciążę ${ }^{10}$ :

„Wara wam od tych świętych murów! Wasze miejsce tam, gdzie krwawe sprawują sądy, gdzie padają ścięte głowy, gdzie oczy wyłupiaja, gdzie się zabija dziecię w łonie matki, gdzie się praktykuje okrutną kastrację"11.

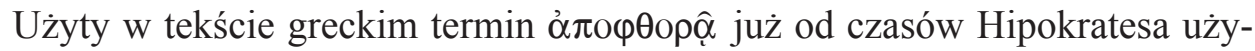
wany był technicznie na oznaczenie sztucznego przerywania ciąży ${ }^{12}$. Ajschylosowi aborcja jawi się więc jako zniszczenie życia dziecka, zabójstwo, które zasługuje na krwawy osąd i karę piekła.

Jaki jest z kolei pogląd na przerywanie ciąży Platona? Temu wybitnemu filozofowi należy po pierwsze postawić pytanie o status ludzkiego płodu. Czy jest on w pełni człowiekiem? Czy posiada już ciało i duszę? Platon bowiem jako pierwszy w historii filozofii wypracował całościową koncepcję osoby ludzkiej oraz podał obszerną naukę o duchowym jej pierwiastku, jakim jest dusza. Wydaje się, że Platon uważał, iż embrion posiada w sobie pierwiastek duchowy, który przybywa ze świata Idei ${ }^{13}$. Takie stanowisko Platona zdawał się później potwierdzać Tertulian, który w dziele De anima stwierdza:

„Tenże Platon w szóstej księdze Praw każe uważać, by przez nieodpowiednie spółkowanie nie uszkodzić nasienia, bo mogłoby się to odbić ujemnie zarówno na ciele, jak na duszy dziecka" ${ }^{14}$.

$\mathrm{W}$ okresie prenatalnym istnieje więc w człowieku jakiś pierwiastek duchowy. Obserwację Tertuliana zakładał wcześniej sam Platon w dialogu Uczta:

„W zapłodnieniu jest jakiś pierwiastek wiekuisty, nieśmiertelny, o ile to być może w istotach śmiertelnych. A przecież, wobec tego, na cośmy się zgodzili, musi człowiek i nieśmiertelności pragnąć, jeżeli przedmiotem miłości jest

${ }^{10}$ Por. Longosz, Ojcowie Kościoła, s. 235-236.

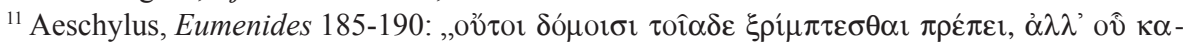

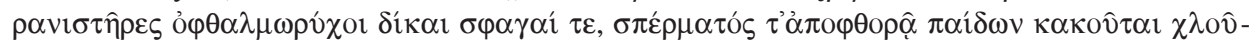

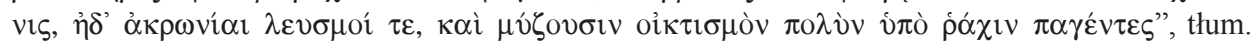
S. Srebrny: Ajschylos, Tragedie, Warszawa 1954, 450; por. także E. Nardi, Procurato aborto nel mondo greco romano, Milano 1971, 49-52; Longosz, Ojcowie Kościoła, s. 236.

${ }^{12}$ Por. F. Dölger, Das Lebensrecht des ungeborenen Kindes und die Fruchtabtreibung in der Bewertung der heidnischen und christlichen Antike, ACh 4 (1933) 16-18; Longosz, Ojcowie Kościoła, s. 236.

${ }^{13}$ Por. A. Muszala, Embrion ludzki w starożytnej refleksji teologicznej, Kraków 2009, 96.

${ }^{14}$ Tertullianus, De anima 25, 9, CCL 2, 821: „At idem [Plato] [...] monens cavere, ne vitiatio seminis ex aliqua vilitate concubitus labem corpori et animae supparet", thum. M. Michalski, ALP 1, Warszawa 1975, 241. 
wieczne posiadanie dobra. Więc wynika to rzeczywiście z naszych rozważań, że się Eros i do nieśmiertelności odnosi”"15.

Wynika więc z tego, że, zdaniem Platona, płód ma już w sobie duszę nieśmiertelną, a nadto, że dusza ludzka przekazywana jest w akcie seksualnym przez mężczyznę, co by świadczyło, że Platon był wyznawcą traducjanizmu. Za tą tezą mogłoby świadczyć przekonanie Filozofa, iż rola kobiety w akcie poczęcia jest tylko receptywna: kobieta przyjmuje nasienie do swego łona i stwarza warunki do jego rozwoju. Miejscem wzrostu nowego człowieka jest macica, którą Platon przyrównuje do gleby (przyjmującej nasienie). To właśnie w macicy, jego zdaniem, następuje zapłodnienie. I właśnie w procesie zapłodnienia przekazywany jest embrionowi jakiś element nieśmiertelny. Zdaniem Andrzeja Muszali, trudno jest jednak dziś jednoznacznie odpowiedzieć, czy Platon utożsamiał to rzeczywiście z tym, co obecnie określa się mianem ,,animacji równoczesnej". Teza ta według tego badacza pozostaje bardziej w sferze domysłów, jakkolwiek nie jest pozbawiona podstaw ${ }^{16}$. Dla starozytnego Filozofa, jak zauważa Pseudo-Plutarch, ,embrion jest bytem żywym; i rzeczywiście - przemieszcza się w łonie matki i odżywia"17.

Skoro Platon zakładał, że płód jest istotą cielesno-duchową, to jaki w takim razie był jego stosunek do aborcji? Otóż Platon, nie tylko że w pewnych sytuacjach zakłada aborcję, a nawet uśmiercanie dzieci po urodzeniu, ale wręcz ją czasami nakazuje. Taki jego pogląd zdaje się wynikać po pierwsze z jego doktryny polityczno-społecznej, którą wyłożył przede wszystkim w dwu swoich dziełach, a mianowicie w Państwie i Prawach. Filozof ten w swojej doktrynie polityczno-prawnej przeciwstawia ludzi wybranych zwykłemu szaremu tłumowi. Tylko ci pierwsi, ćwicząc się w dialektyce i cnocie zdolni są do poznania idei i sprawowania rządów nad żyjącym złudzeniami tłumem. Zgodnie z tym państwo idealne obejmować winno dwie klasy ludzi: rządzących i rządzonych. Pierwsza, nazwana strażą państwa, rozpada się z kolei na rządców i wojowników, czyli obrońców; druga - to klasa pracująca i wytwarzająca dla całej społeczności środki do zaspokajania potrzeb. Doborowi ludzi do klasy stróżów prawa miał służyć system wychowania. Przywiązując do wychowania bardzo wielkie znaczenie, wysuną Platon postulat przymusowego publicznego wychowania obywateli. Należyte wychowanie i wykształcenie stróżów państwa spowoduje, że zgodnie z przysłowiem wszystko stanie

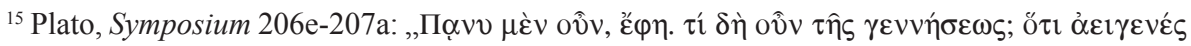

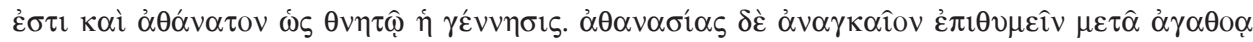

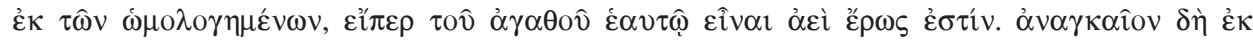

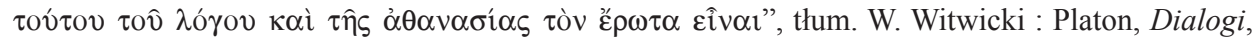
II, Kęty 1999, 72.

${ }^{16}$ Por. Muszala, Embrion ludzki, s. 97-98.

${ }^{17}$ Ps-Plutarchus, Placita philosophorum 5, 15, ed. J. Mau, Plutarchi moralia V 2, 1, Leipzig 1971 ; Muszala, Embrion ludzki, s. 98. 
się wspólne między przyjaciółmi: na zasadach wspólności opierać się będzie całe życie członków tej klasy. Nie byłoby tam ani własności prywatnej, ani indywidualnej rodziny. Kobiety zyskałyby równouprawnienie z mężczyznami. Wszystkie kobiety mają żyć wspólnie ze wszystkimi mężczyznami. Mieszkać ani odżywiać się osobno nie będzie wolno. Pary małżeńskie byłyby dobierane przymusowo na czas określony pod kątem uzyskania jak najdoskonalszego potomstwa. Dzieci, spośród których słabsze ulegałyby zgładzeniu, przebywałyby w publicznych zakładach, gdzie byłyby wychowywane na wojowników i filozofów. Uważane za wspólną własność państwa, nie znałyby swoich rodziców. W ten sposób całe społeczeństwo spajałaby miłość rodzinna: wszystkie dzieci kochałyby dorosłych jak rodziców, a dorośli miłowaliby całą młodzież jak swe własne dzieci. W całości swej system ten odznaczał się niezwykłą surowością. Polegał na odgórnym ustalaniu wszystkiego: wierzeń religijnych, literatury, obcowania płciowego, sposobu odżywiania się, instrumentów muzycznych, a nawet melodii i tonacji muzycznych, zabaw itd. W takiej właśnie perspektywie należy odczytywać również teksty Platona, w świetle których widzi on miejsce dla aborcji. Władza państwa miała prawo regulować liczbę dzieci, które miały być jak najlepsze i jak najsilniejsze. W jego Prawach czytamy:

„Młodej małżonce i młodemu małżonkowi musi przede wszystkim leżeć na sercu, ażeby możliwie najpiękniejsze i najlepsze dzieci przekazać państwu"18.

Jaki los przewidywał Platon dla dzieci, które urodziły się słabe:

„Dzieci tych gorszych, gdyby się tym innym jakieś ułomne urodziło, to też w jakimś miejscu, o którym się nie mówi i nie bardzo wiadomo, gdzie by ono było, ukryć jak należy" ${ }^{\prime 19}$.

Mając na względzie taki właśnie cel Platon wywodzi:

„We wszystkich tych wypadkach najwyższa nasza i najdostojniejsza władza będzie musiała rozważyć, co trzeba zrobić, gdy jest zbyt wielka lub zbyt mała ilość dzieci, i znaleźć sposób, żeby utrzymała się niezmiennie owa liczba pięciu tysięcy czterdziestu domów. Sposobów jest wiele, bo można i na zmniejszenie się płodności wpływać, jeżeli jest zbyt obfita, i odwrotnie, na zwiększenie się liczby urodzin" ${ }^{20}$.

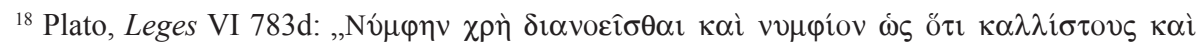

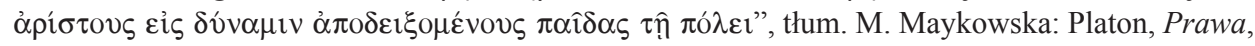
Warszawa 1960, 198.

${ }^{19}$ Plato, Respublica V 9, 461bc, thum. W. Witwicki: Platon, Państwo - Prawa, Kęty 1999, 162.

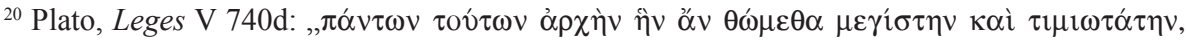
$\alpha$

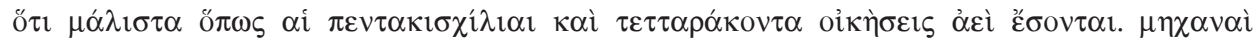

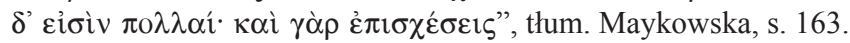


Sposobem na zmniejszenie płodności była dla Platona również aborcja, a nawet zabójstwo lub porzucenie narodzonego już dziecka. W swoim Państwie pisze wyraźnie:

„Kobiety i mężczyźni poza latami rozpłodu [...] będą mieli rozkaz starać się, żeby najlepiej ani jeden owoc takiego stosunku nie ujrzał światła dziennego, jeśliby się zalagł [...]. Gdyby jednak na świat przyszedł jakoś wbrew usiłowaniom, to położyć to gdzieś tak, żeby nie było pożywienia dla niego" ${ }^{\text {"21 }}$.

W świetle takiego poglądu Platona odnośnie aborcji rodzi się jedno ważne pytanie, jak on mógł pogodzić takie stanowisko z uznawaniem z drugiej strony animacji płodu ludzkiego? Próbą odpowiedzi na to pytanie może być hipoteza, jaką stawia ks. Andrzej Muszala, który próbuje wytłumaczyć stanowisko Platona w świetle jego dualizmu między materią a duchem oraz poglądu o preegzystencji i metempsychozy dusz: ,[...] można się tu pokusić o postawienie dość śmiałej hipotezy - przerywanie ciąży było, w myśl platońskiego dualizmu i opozycyjności pierwiastka materialnego i duchowego, dość logiczne. Platon zakładał preegzystencję dusz i ich metempsychozę; dusze nie giną, a jedynie wcielają się w następne formy organiczne. Zniszczenie ciała ludzkiego nie oznacza zatem kresu istnienia duszy; od tego momentu znajduje sobie ona inne ciało, być może nawet bardziej odpowiednie i lepiej uformowane, w którym nadal prowadzi swoją egzystencję. Co więcej, skoro ciało jest dla duszy ciężarem, a związek z nim poniżeniem - to wyzwolenie $\mathrm{z}$ jego więzów jeszcze przed narodzeniem może okazać się dla duszy zbawienne. Istnieje wówczas możliwość, że zostanie ona wyzwolona z uciążliwej tułaczki po świecie materialnym i ostatecznie przeniesiona do świata Idei. W takim świetle można zrozumieć, że Platon nie sprzeciwiał się zabiegom spędzania płodu ludzkiego"22.

Jak w świetle poglądów platońskich przedstawia się problem przerywania ciąży u Arystotelesa? Rozpocznijmy od antropologii Stagiryty: Arystoteles bowiem jako pierwszy wypracował kompletną koncepcję animacji ludzkiego embrionu, która wywarła olbrzymi wpływ na refleksję filozoficzno-teologiczną kilkunastu następnych wieków ${ }^{23}$. By należycie zrozumieć tę koncepcję, należy przypomnieć za A. Muszalą podstawowe założenia Arystotelesowskiej metafizyki. Przyjmuje on dwie pary kategorii metafizycznych, które stanowią fundament opisu wszystkich bytów. Pierwszą z nich jest materia - forma

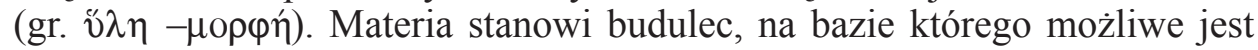

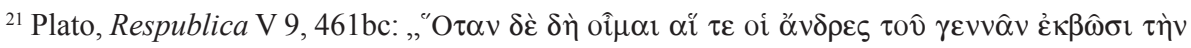

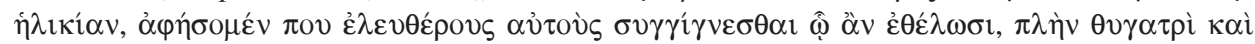

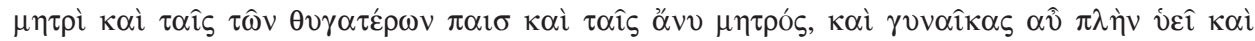

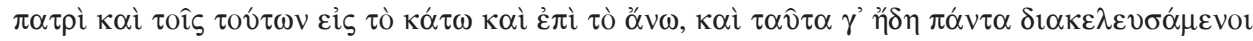

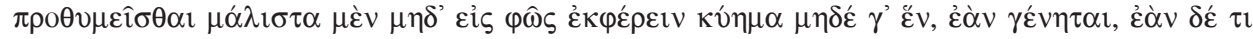

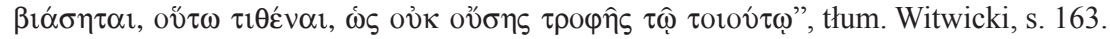

${ }^{22}$ Muszala, Embrion ludzki, s. 101-102.

${ }^{23}$ Por. tamże, s. 102. 
ukształtowanie („u-formowanie”) jakiegoś konkretnego przedmiotu. Np. blok marmurowy jest materią, z którego rzeźbiarz może wydobyć jakiś kształt: posag, kolumnę, obelisk. Według Arystotelesa, nie istnieje jednak materia zupełnie nieuformowana; zawsze posiada ona jakiś kształt, który potem może być zmieniony. Przekształcanie rzeczywistości, a tym samym rozwój świata, polega na przechodzeniu jednych form w drugie; materia może utracić swoją poprzednią formę i zostać przekształcona w coś innego. Drugą parę kluczowych

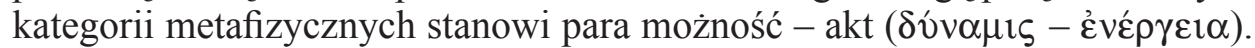
Coś może być czymś potencjalnie (byt w możności), choć nie jest jeszcze tym aktualnie (czyli nie jest jeszcze bytem w akcie), np. blok marmuru (byt w możności) może kiedyś stać się posagiem (bytem w akcie), lub dziecko jest potencjalnym dorosłym, tzn. jest już dorosłym w możności, choć nie jest jeszcze nim aktualnie ${ }^{24}$.

W świetle tych założeń prowadzi Arystoteles badania nad rozwojem embrionu, co czyni głównie w traktacie De anima. Dusza jest tym, co formuje ciało, nadaje mu kształt, żywotność i warunkuje wzrost. Dusza jest zatem formą ciała; to ona decyduje o jego żywotności, poruszaniu się i rozmnażaniu; to ona kształtuje je z materii nieożywionej. Dusza jest tym czymś, co sprawia, że byt w możności (nieożywiona materia) przechodzi w następną formę, jaką jest ciało (byt w akcie). Dusza jest zatem pierwszą aktywnością ciała naturalnego i organicznego, posiadającego życie potencjalnie ${ }^{25}$.

Arystoteles rozróżniał trzy rodzaje duszy: wegetatywną (roślinną) $-\theta \rho \varepsilon \pi-$

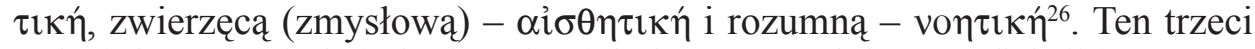
rodzaj duszy posiada jedynie człowiek, który ma zdolność refleksji i przeprowadzania rozumowania, stąd też musi posiadać duszę rozumną, która wyraża się w życiu i aktach rozumnych, które są podstawą wolnej woli ${ }^{27}$.

Kolejnym pytaniem Arystotelesa było: jaką naturę ma dusza rozumna czy jest wyższym przejawem życia biologicznego, czy też jest czymś więcej i czy jest niezależna od sfery cielesnej? Czy dusza jest formą wysublimowanej materii, czy też jest czymś zupełnie niematerialnym, doskonałym, boskim? Nie jest oczywiste, w jakim stopniu Arystoteles bazował tu na rozważaniach Platona, jednak w tej kwestii poszedł właśnie śladem swojego mistrza z Aten, stwierdzając, że dusza ludzka (rozumna) - skoro ma być formą ciała - musi być niematerialna; co więcej, musi pochodzić z zewnątrz ( $\theta \dot{\rho} \rho \alpha \theta \varepsilon v)$. Rozum bowiem sam w sobie jest niematerialny; działa w sposób niezależny od wszelkich organów. Chociaż Arystoteles widział ścisły związek pomiędzy rozumem a aktywnością mózgu człowieka, to jednak nie uważał duszy rozumnej za ja-

\footnotetext{
${ }^{24}$ Tamże.

${ }^{25}$ Por. Aristoteles, De anima 412a; Muszala, Embrion ludzki, s. 103-104.

${ }^{26}$ Por. Aristoteles, De anima 413a25-b2; 415a2; Muszala, Embrion ludzki, s. 104.

${ }^{27}$ Por. Aristoteles, De anima 427a-b; 429a-b; Muszala, Embrion ludzki, s. 104.
} 
kąś emanację centralnego układu nerwowego ${ }^{28}$. Rozum (dusza intelektualna) wchodzi do embrionu od zewnątrz, jest boskiego pochodzenia ${ }^{29}$.

Według Arystotelesa embrion ludzki posiadał już duszę rozumną:

„Trudno przypuścić, żeby embrion był zgoła bez duszy, pozbawiony całkowicie wszelkiego rodzaju życia" 30 .

Skoro embrion od samego początku posiada duszę, to w jaki sposób zostaje ona w nim umieszczona? - to kolejny problem Stagiryty. Thumaczy on cały proces animacji ludzkiego embrionu w oparciu o kategorie materii i formy. Według niego każda z płci odgrywa osobną rolę w procesie zapłodnienia:

„Samiec daje formę i zasadę ruchu, a samica ciało, czyli materię"31.

„Samica z konieczności dostarcza ciała, czyli określonej ilości materii, podczas gdy samiec nie podlega tej samej konieczności. [...] Zatem ciało noworodka pochodzi od samicy, dusza od samca; dusza bowiem jest istotą danego ciała" ${ }^{32}$.

Czy wobec powyższego Arystoteles zakładał traducjanizm? Tak. Ale według Stagiryty dotyczy to duszy wegetatywnej i zwierzęcej (zmysłowej), ale nie duszy rozumnej (vov̂s), gdyż ta ostatnia przychodzi z zewnątrz ( $\theta \hat{\rho} \rho \alpha \theta \varepsilon v)$; ma więc charakter boski. Na ogół przyjmuje się, że - według myśli Arystotelesa dokonuje się to w przypadku płodów męskich około 40., a przypadku żeńskich - około 90. dnia po poczęciu ${ }^{33}$.

Skoro płód ludzki posiada już duszę rozumną, to jaki jest stosunek Arystotelesa do aborcji? W Polityce czytamy:

„W kwestii usuwania czy wychowywania noworodków winno obowiązywać prawo, by nie wychowywać żadnego dziecka wykazującego kalectwo. Biorąc jednak pod uwagę liczbę dzieci, należy wobec tego, że istniejące obyczaje nie pozwalają usuwać żadnego noworodka, liczbę urodzin prawem ograniczyć; jeśli zaś jacyś obcujący ze sobą małżonkowie poczną dziecko ponad tę liczbę, należy spowodować jego poronienie, zanim jeszcze czucie i życie w nie wstą-

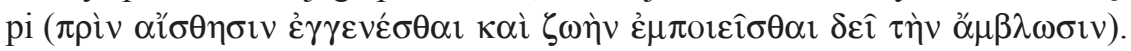
Bo co tu jest godziwe a co nie, zależeć będzie od tego, czy płód już czucie i życie posiada" ${ }^{\prime 4}$.

${ }^{28}$ Por. Muszala, Embrion ludzki, s. 105; Aristoteles, Analytica posteriora II 19.

${ }^{29}$ Por. Aristoteles, De generatione animalium II 736b.

${ }^{30}$ Tamże II 736a, tłum. P. Siwek: Arystoteles, O rodzeniu się zwierzat, Biblioteka Klasyków Filozofii 130, Warszawa 1979, 74.

${ }^{31}$ Tamże I 729a, thum. Siwek, s. 50; Muszala, Embrion ludzki, s. 107.

${ }^{32}$ Aristoteles, De generatione animalium II 738b, thum. Siwek, s. 82.

${ }^{33}$ Por. Muszala, Embrion ludzki, s. 110-111.

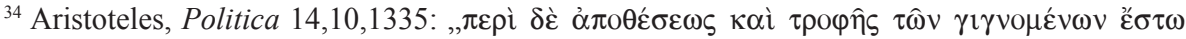

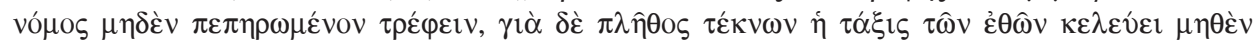


Jak Platon, Arystoteles dopuszcza więc przy pomocy sztucznego poronienia regulację przyrostu naturalnego. Dopuszcza aborcję płodu do momentu, gdy wstąpi w nie czucie i życie. Czy ma to miejsce w czterdziestym albo dziewięćdziesiątym dniu po poczęciu? Arystoteles wyraźnie tego nie deklaruje.

Przejdźmy do kolejnego ważnego nurtu w antycznej filozofii, jakim był stoicyzm. Jaki był pogląd stoików na animację ludzkiego płodu? Stoicy zakładając materialistyczną strukturę duszy ludzkiej, aspirowanej wraz z wdychanym powietrzem, uważali, iż jej umiejscowienie w ciele następuje w momencie urodzenia. Sam zaś moment hominizacji miał zachodzić jeszcze później, gdy dziecko zaczynało wykazywać przejawy aktywności duszy rozumnej. To określenie momentu animacji embrionu ludzkiego w momencie narodzin implikowało nieosobowe podejście do mającego się narodzić przez cały okres jego życia płodowego.

W jaki sposób ten pogląd implikował ich stosunek do przerywania ciąży? Stoicy wysoko stawiali wartości życia rodzinnego, wierności małżeńskiej oraz posiadania odpowiedniej ilości dobrze wychowanych dzieci. Mężczyzna winien postępować zgodnie z prawem natury, tzn. założyć własną rodzinę, dbać o jej rozwój i przekazać społeczeństwu wartościowych obywateli. Stąd też dzieci winny się rodzić w sprzyjających warunkach oraz w dobrej sytuacji rodzinnej. Sztuczne poronienie było usprawiedliwione tylko pod pewnymi zastrzeżeniami, jak trudna sytuacja rodzinna czy zagrożenie zdrowia/życia matki. Niegodziwe natomiast byłoby gdyby je wykonano dla celów egoistycznych, np. ze względów estetycznych czy w celu ukrycia zdrady małżeńskiej. Zabiegu można było dokonać w każdym momencie okresu ciążowego, gdyż płód nie był przez nich uznawany za człowieka ${ }^{35}$.

Przejdźmy do literatury rzymskiej, znajdującej się pod wpływem stoicyzmu. Jak łacinnicy oceniali aborcję? We wspomnianej już mowie obrończej Oratio pro Cluento Avito Cyceron opowiada o pewnej kobiecie z Miletu, która przy pomocy środków farmakologicznych dopuściła się sztucznego poronienia. Mówca dodaje, że za ten czyn została skazana na karę śmierci ${ }^{36}$. W następujących słowach rzymski orator ocenia to zdarzenie:

„Słusznie, ponieważ zgładziła nadzieję ojca, pamiątkę jego imienia, podporę rodu, dziedzica domu, i przyszłego obywatela Rzeczypospolitej. Tamta

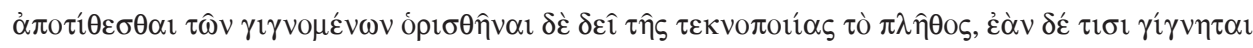

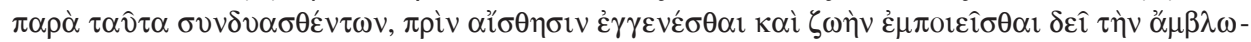

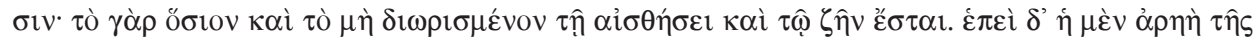

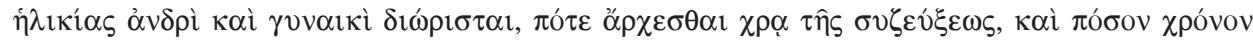

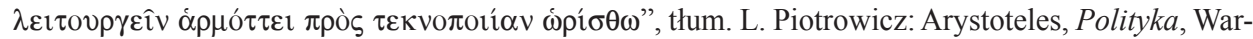
szawa 1964, 331; por. Muszala, Embrion ludzki, s. 113.

${ }^{35}$ Por. Muszala, Embrion ludzki, s. 120-121.

${ }^{36}$ Por. Cicero, Oratio pro Cluento Avito 11, 32: „partum sibi ipsa medicamentis abegisset, rei capitalis esse damnatam".
} 
kobieta własnemu ciału gwałt zadając, sama sobie była przyczyną swych cierpień"37.

Z tych słów wynika, że Mówca dostrzega w tej aborcji z jednej strony zadanie przez tę kobietę gwałtu własnemu ciału, $\mathrm{z}$ drugiej zaś uznaje ten czyn za zabójstwo, w którym zgładzono przyszłego obywatela rzymskiego.

Wiele ciekawych informacji na temat zjawiska aborcji wśród kobiet rzymskich, a także swój osobisty stosunek do tego zjawiska przekazał nam rzymski poeta Owidiusz z czasów cesarza Augusta. Było wówczas wiele kobiet, które z powodu próżnej troski o urodę decydowały się na sztuczne poronienie. W jednym z wierszy Poeta stwierdza:

„Teraz gwałt zadaje brzuchowi ta, która chce być widziana jako urodziwa:

I rzadko w tym życiu jest tak, aby chciała być matką"38.

Do zjawiska aborcji nawiązuje Owidiusz zwłaszcza w swoim dziele poetyckim Amores, W II księdze tego zbioru poetyckiego, wiersz 13. rozpoczyna od przedstawienia faktu dokonanej aborcji przez jego kochankę Korynnę, która lekkomyślnie usiłując pozbyć się poczętej z nim ciąży przypłaciła to zdrowiem i znalazła się w niebezpieczeństwie utraty życia ${ }^{39}$. Korynna dokonała tego bez jego wiedzy, co wzbudziło w nim gniew, a jeszcze bardziej zgrozę ${ }^{40}$. Poeta prosi bogów, by litościwie spojrzeli na nich oboje, a w zakończeniu wiersza zwraca się do bogini narodzin z następującym błaganiem:

„Przyjdź łaskawa Litynio i wysłuchaj mojego błagania! Ona jest godna pomocy od ciebie, obdarz ją życiem! Ja sam ofiaruję kadzidło na twoim dymiącym ołtarzu, także pochwalny podarek położę u twoich stóp. I napiszę przy tym: «O ratunek dla Korynny od Naso»! I przyjmij w ten sposób dedykowany dar" ${ }^{\text {”4 }}$.

Świadectwem osobistej oceny aborcji przez Owidiusza jest jego kolejny 14. wiersz z II księgi Amores. Poeta opowiada w nim o kobietach, które, aby ciało pozbawić zmarszczek, podejmują wzbudzającą zgrozę walkę, dopuszczając się zbrodni w swoim łonie ${ }^{42}$. Dla Owidiusza sztuczne poronienie jawi

37 Tamże, tłum. E. Rykaczewski: Mowy Marka Tuliusza Cycerona, II, Paryż 1870, 44; por. Longosz, Ojcowie Kościoła, s. 238.

${ }^{38}$ Ovidius, Nux 23-24: „Nunc uterum vitiat, quae vult formosa videri: Raroque in hoc aevo est, quae velit esse parens", tłum. własne.

${ }^{39}$ Por. Ovidius, Amores II 13: „Dum labefactat onus gravidi temeraria ventris, / in dubio vitae lassa Corinna iacet”, thum. własne.

${ }^{40}$ Tamże II 13, 3-4: ,illa quidem clam me tantum molita pericli / ira digna mea; sed cadit ira metu", tłum. własne.

${ }^{41}$ Tamże II 13, 21-26: „lenis ades precibusque meis fave, Ilithyia! / Digna est, quam iubeas muneris esse tui. / Ipse ego tura dabo fumosis candidus aris, / ipse feram ante tuos munera vota pedes. / adiciam titulum: «servata Naso Corinna!», / tu modo fac titulo muneribusque locum", thum. własne.

${ }^{42}$ Por. tamże II 14, 7-8: ,[...] ut careat rugarum crimine venter, / sternetur pugnae tristis harena tuae". 
się tutaj jako zbrodnia przeciw ludzkości. Gdyby w ten sam sposób wcześniej postępowało wiele innych kobiet, świat już dawno uległby zagładzie na skutek wyludnienia:

„Gdyby ten sam zwyczaj podobał się matkom w dawnych czasach, dawno już rodzaj ludzki uległby zagładzie na skutek tej winy. I potrzeba byłoby nowego człowieka, który dałby początek naszemu rodowi, który w wyludnionym świecie kładłby nowe podwaliny. Jaka potęga złamałaby Priama, gdyby boska Tetyda odmówiła noszenia ciężarnego łona? Gdyby bliźniaków w nabrzmiałym ciele zabiła Ilia, nigdy nie byłoby założyciela miasta, które rządzi ziemią; Gdyby Wenus dopuściła się gwałtu na Eneaszu w jej ciężarnym łonie, to przyszły świat zostałby pozbawiony pokolenia cezarów"43.

A do kobiety, która z takiego powodu dopuszcza się sztucznego poronienia Owidiusz w tym wierszu zwraca się w następujących słowach:

„Także i ty, która tak piękna przyszłaś na ten świat, zostałabyś zgładzona, gdyby twoja matka dopuściła się tego, czego ty się dopuściłaś" ${ }^{44}$.

Względem zaś własnej osoby Poeta dodaje następującą uwagę:

„I ja sam, chociaż lepiej byłoby dla mnie umrzeć kochając, nigdy nie zobaczyłbym dnia, gdyby moja matka odmówiła mi tego" ${ }^{45}$.

Poeta $\mathrm{w}$ dramatycznych słowach pyta tego typu kobiety:

„Czemu z ciężarnej winnej latorośli, zielone jeszcze zrywasz grono? Czemu okrutną ręką zrywasz kwaśne jeszcze owoce?" ${ }^{46}$.

A następnie kieruje w ich stronę imperatyw:

„Samorzutnie przecież spada to, co dojrzewa, pozostaw więc, co tam wzrasta, niech rośnie, to tylko jedna mała chwila, za cenę życia" ${ }^{{ }^{4}}$.

Kobiety te jednak postępują gorzej niż dzikie zwierzęta:

${ }^{43}$ Tamże II 14, 9-18: „si mos antiquis placuisset matribus idem, / gens hominum vitio deperitura fuit; / quique iterum iaceret, generis primordia nostri, / in vacuo lapides orbe, parandus erat. / quis Priami fregisset opes, si numen aquarum / iusta recusasset pondera ferre Thetis? / Ilia si tumido geminos in ventre necasset, / casurus dominae conditor Urbis erat; / si Venus Aenean gravida temerasset in alvo, / Caesaribus tellus orba futura fuit", thum. własne.

${ }^{44}$ Tamże II 14, 19-20: „tu quoque, cum posses nasci formosa, perisses, / temptasset, quod tu, si tua mater opus".

${ }^{45}$ Tamże II 14, 21-22: ,ipse ego, cum fuerim melius periturus amando, / vidissem nullos matre negante dies".

${ }^{46}$ Tamże II 14, 23-24: „Quid plenam fraudas vitem crescentibus uvis, / pomaque crudeli vellis acerba manu?".

${ }^{47}$ Tamże II 14, 25-26: „sponte fluant matura sua - sine crescere nata; / est pretium parvae non leve vita morae". 
„Tego żadna tygrysica nie czyniła w gąszczach Armenii, także lwica nie miała serca, by niszczyć swe nieurodzone młode! A jednak delikatne dziewczyny to czynią, ale nie bezkarnie; jest często tak, że kto zabija owoc własnego łona, sam umiera" ${ }^{48}$.

Kończąc ten wiersz Poeta mimo wszystko ma świadomość, że nawet te mocne słowa, są rzucane na wiatr, i nie wierzy w ich skutek ${ }^{49}$. W ostatnim wersie zwraca się jednak z prośbą do bogów, by raz jeszcze czyn takiej kobiety uszedł jej bezkarnie:

„Łaskawi bogowie pozwólcie, by ona bezkarnie tym razem zgrzeszyła, drugi występek niech przyniesie już karę"50.

W kwestii sztucznego poronienia Owidiusz ma więc jednoznaczną ocenę: przerwanie ciąży jest godną kary zbrodnia, w wyniku której pozbawia się życia istotę, w której życie to dopiero zaczyna kiełkować i wzrastać. Ta zbrodnia ma swój wymiar społeczny, godzi w rozwój społeczeństw i narodów, jest zjawiskiem, które w przyrodzie trudno rozpoznać poza światem ludzi. A częstym motywem takiej zbrodni jest zwykłe wygodnictwo, troska o komfort życia i piękny zewnętrzny wygląd.

Taki motyw postępowania dotyczy często przede wszystkim kobiet zamożnych, ze znakomitych rodów, co zresztą zauważa późniejszy satyryk Juwenal: „A rzadko położnicę trzyma złote łoże ${ }^{51}$. Na tym tle tenże poeta szkicuje postawę kobiet ubogich:

„Innej kłopot, związany z potomstwem, nie zraża, i pomimo ubóstwa dziecko karmić może" 52 .

$\mathrm{Na}$ tle postawy tych kobiet, jakie w swoich wierszach piętnują Owidiusz i Juwenal, wymownie brzmią słowa Seneki, który w dziele De consolatione ad Helviam matrem, daje o swojej matce piękne świadectwo przeżywania przez nią macierzyństwa:

„Nigdy nie wstydziłaś się swego licznego potomstwa, jak gdyby miało niekorzystnie świadczyć o twoim wieku. Nigdy zwyczajem innych kobiet, które szukają chwały w swoich kształtach, nie ukrywałaś ciężarnego łona, jak

${ }^{48}$ Tamże II 14, 35-38: „hoc neque in Armeniis tigres fecere latebris, / perdere nec fetus ausa leaena suos. / At tenerae faciunt, sed non inpune, puellae; / saepe, suos utero quae necat, ipsa perit".

${ }^{49}$ Por. tamże II 14, 41-42: „Ista sed aetherias vanescant dicta per auras, / et sint ominibus pondera nulla meis!"”.

${ }^{50}$ Tamże II 14, 43-44: „di faciles, peccasse semel concedite tuto, / et satis est; poenam culpa secunda ferat!".

${ }^{51}$ Iuvenalis, Satura VI 594: „,sed iacet aurato uix ulla puerpera lecto”, thum. własne.

${ }^{52}$ Tamże VI 592-593: „Hae tamen et partus subeunt discrimen et omnis / nutricis tolerant fortuna urguente labores", tłum. własne. 
gdyby nieprzyzwoitego brzemienia, ani nie udaremniłaś poczętych w swoich wnętrznościach nadziei potomstwa" ${ }^{\text {33 }}$.

Konkludując można powiedzieć, że w starożytnej Grecji i Rzymie, chociaż uważano, że dzieci stanowią błogosławieństwo bogów i bogactwo człowieka, a bezpłodność jest nieszczęściem i karą bożą, to z drugiej strony dopuszczano się zabijania dzieci w łonie matki, a nawet uśmiercania ze względów eugenicznych dzieci już urodzonych. Takie stanowisko zajmowali Platon i Arystoteles, pomimo poglądu o animacji płodu już w łonie matki. Stoicy, którzy uważali, że płód jest tylko częścią matki, nie widzieli problemu, by dokonywać sztucznego poronienia w każdym momencie okresu ciążowego. Aborcja była więc wykonywana, choć praktyce tej towarzyszyło także społeczne potępienie, które widziało w niej zbrodnię godną kary boskiej i ludzkiej, czego świadectwem są dzieła Ajschylosa, Cycerona, Owidiusza i Juwenala.

\section{ETHICAL-ANTHROPOLOGICAL ASPECTS OF THE ABORTION IN THE LIGHT OF THE CLASSICAL LITERATURE OF GREECE AND ROME}

\section{(Summary)}

In ancient Greece and Rome, though it considered that children constituted God's blessing and the wealth of the man, and the sterility is fatality and the divine punishment, on the other hand one committed kills of children in the mother's womb, and even killings from favour of eugenic children already born.

Such position took up Plato and Aristotle, despite the view about the animation of the foetus already in the mother's womb. Stoics who thought that the foetus was only a part of the mother, they did not see the problem, to make the abortion in every moment the maternity period.

The abortion was so executed, however to this practice accompanied also and the social condemnation which saw in the abortion the crime worthy of the divine punishment and human, and expression of this are works of Aeschylus, Cicero, Ovid and Juvenal.

${ }^{53}$ Seneca, De consolatione ad Helviam matrem 16, 3, thum. L. Joachimowicz: L.A. Seneka, Pisma filozoficzne, I, Warszawa 1965, 529. 
